\title{
Genetic variability in Astyanax altiparanae Garutti \& Britski, 2000 (Teleostei, Characidae) from the Upper Paraná River basin, Brazil
}

\author{
Maria Dolores Peres ${ }^{1}$, Marcio dos Santos Vasconcelos ${ }^{2}$ and Erasmo Renesto ${ }^{1,3}$ \\ ${ }^{1}$ Universidade Estadual de Maringá, Núcleo de Pesquisas em Limnologia, Ictiologia e Aqüicultura, \\ Maringá, PR, Brazil. \\ ${ }^{2}$ Centro Integrado de Ensino Superior, Campo Mourão, PR, Brazil. \\ ${ }^{3}$ Universidade Estadual de Maringá, Departamento de Biologia Celular e Genética, Maringá, PR, Brazil.
}

\begin{abstract}
Allozyme data was used to assess the genetic diversity Astyanax altiparanae populations from the floodplain of the Upper Paraná River (PR). Specimens were collected in the southern Brazilian state of Paraná from PR in Porto Rico municipality and Ribeirão Ficha (RF) in Ubiratã municipality. The authors used $15 \%(\mathrm{w} / \mathrm{v})$ corn starch gel electrophoresis to identify 21 putative loci for 13 enzymatic systems: Aspartate aminotransferase, 2.6.1.1 (AAT), Acid phosphatase, 3.1.3.2 (ACP), Esterase, 3.1.1.1 (EST), Glycerol-3-phosphate dehydrogenase, 1.1.1.8 (G3PDH), Glucose-6-phosphate dehydrogenase, 1.1.1.49 (G6PDH), Glucose-6-phosphate isomerase, 5.3.1.9 (GPI), Iditol dehydrogenase, 1.1.1.14 (IDDH), Isocitrate dehydrogenase - NADP ${ }^{+}, 1.1 .1 .42$ (IDH), L-Lactate dehydrogenase, 1.1.1.27 (LDH), Malate dehydrogenase, 1.1.1.37 (MDH), Malate dehydrogenase - NADP ${ }^{+}$, 1.1.1.40 (MDHP), Phosphoglucomutase, 5.4.2.2 (PGM), and Superoxide dismutase, 1.15.1.1 (SOD). The proportion of polymorphic loci were estimated as $52.38 \%$ in the PR population and $38.10 \%$ in the RF population. Expected estimated heterozygosities were $0.1518 \pm 0.0493$ for the PR population and $0.0905 \pm 0.0464$ for the RF population. The $A$. altiparanae heterozygosity data were similar to previous estimates for other PR basin characid species. Allele frequencies were significantly different between the PR and RF populations in respect to some loci (Acp-1, G3pdh-1, Gpi-A, Iddh-1, Mdhp-1 and Mdhp-2). Wright's statistics for all loci were estimated as $\mathrm{F}_{\text {is }}=0.3919, \mathrm{~F}_{\mathrm{it}}=0.4804$ and $\mathrm{F}_{\mathrm{st}}=0.1455$. Our results show that the $A$. altiparanae populations studied are genetically different and have a high degree of genetic variability.
\end{abstract}

Key words: allozymes, Astyanax, fishes, genetic variability, Paraná River floodplain.

Received: July 23, 2004; Accepted: March 22, 2005.

\section{Introduction}

In the Upper Paraná River (PR) there was an extensive floodplain stretching $480 \mathrm{~km}$ between the municipalities of Três Lagoas $\left(20^{\circ} 48^{\prime} \mathrm{S}, 51^{\circ} 43^{\prime} \mathrm{W}\right)$ in the Brazilian state of Mato Grosso do Sul and Guaíra (240. $04^{\prime}$ S, $54^{\circ} 15^{\prime}$ W) in the Brazilian state of Paraná. When the Porto Primavera hydroelectric dam $\left(22^{\circ} 30^{\prime} \mathrm{S}, 52^{\circ} 57^{\prime} \mathrm{W}\right)$ was inaugurated in 1998 the upper half of the floodplain was submerged by the reservoir and the floodplain reduced to $230 \mathrm{~km}$, this being the last stretch of the Paraná River inside Brazilian territory with a floodplain. The flooding regime of this floodplain is in part controlled by upstream dams (Agostinho et al., 2001), with the Paraná River becoming up to $20 \mathrm{~km}$ wide at the western side when flooding occurs during the rainy season.

Send correspondence to Erasmo Renesto. Universidade Estadual de Maringá, Departamento de Biologia Celular e Genética, Av. Colombo 5790, 87020-900 Maringá, PR, Brazil. E-mail: erenesto@ hotmail.com or renesto@nupelia.uem.br.
For almost twenty years, workers at the Center for limnological studies (Núcleo de Pesquisas em Limnologia, Ictiologia e Aqüicultura - NUPELIA), Maringá State University, Paraná, Brazil, have been studying the ecology of fish, plants, benthos, phytoplankton and zooplankton in the PR floodplain. This research program has revealed that the PR floodplain is home to more than 170 fish species (Agostinho et al., 2001), 33 of which were introduced from the Middle Paraná River (MPR) basin, after the inauguration of the Itaipu hydroelectric dam in 1982 (Julio Jr et al., 2003). While intensive ecological studies have been made on 64 floodplain species (Vazzoler et al., 1997, Agostinho et al., 2001) only a few species have been investigated in terms of their population genetics. Regarding piscine studies, allozyme data was used by Revaldaves et al., (1997) to investigate Prochilodus lineatus, by Peres et al. (2002) to study Hoplias malabaricus and by Zawadzki et al., (2005) to study 15 Hypostomus species, while DNA markers were used by Oliveira et al. (2002) to investigate 
Steindachnerina insculpta and Steindachnerina brevipinna, Oliveira (2004) to study Cichla monoculus, and by Sekine et al. (2002) to study Pseudoplatystoma corruscans.

According to Vida (1994) The future of species diversity is in the genetic diversities of the species. In general, the higher the maintained genetic diversity, the higher the adaptability and, consequently, the survival probability of species in a changing world which means that information on genetic variability of the species to be conserved is essential to conservation programs.

Workers NUPELIA have used allozyme electrophoresis to study the genetic variability of ten of the most abundant PR floodplain fish species, including Astyanax altiparanae (Garutti \& Britski, 2000) which is one of the most abundant fish in the PR basin. It has been reported that in the Paraná River A. altiparanae feeds mainly on insects and microcrustaceans (Luz and Okada, 1999) while in streams it feeds mainly on plants (Abes, 1998). In this species, spawning occurs in several batches from September to March (spring through summer in the Southern Hemisphere), the first sexual maturation length being about 6.9 $\mathrm{cm}$ and at this length about $50 \%$ of $A$. altiparanae are reproducing (Vazzoler et al., 1997). In the PR basin, A. altiparanae is recognized as one of the most important forage and food resources for many piscivorous fish species that are commercially exploited. Because of its ecological importance, basic knowledge of the genetic variability of $A$. altiparanae populations is fundamental to in helping ecologists construct future conservation guidelines for the PR basin.

We chose to investigate allozymes because their role in metabolism and adaptation strategies is currently better understood than that of DNA markers. A further advantage of using allozyme electrophoresis is that this technique can detect higher heterozygosity per locus than can be detected using dominant RAPD markers because with these the estimated heterozygosity cannot be higher than 0.50 .

The aim of the work described in this paper was to use allozyme data to estimate the genetic variability of two A. Altiparanae populations, one from the Upper Paraná River and the other from the small Ribeirão Ficha (both in Paraná state). We also used our data to shed more light on the factors that maintain genetic variability in natural populations.

\section{Material and Methods}

From March to August (autumn through winter) 2002, 31 adult Astyanax altiparanae (Garutti \& Britski, 2000) (Figure 1) were caught from a site $\left(22^{\circ} 45^{\prime} 60^{\prime \prime} \mathrm{S}\right.$, $53^{\circ} 15^{\prime 2} 2$ ” W; Figure 2) on the Upper Paraná River (PR) in Porto Rico municipality where the Paraná River is about $4 \mathrm{~km}$ wide and the mean water temperature oscillate between $18^{\circ} \mathrm{C}$ in winter and $30^{\circ} \mathrm{C}$ in summer (Thomaz et al., 1997).

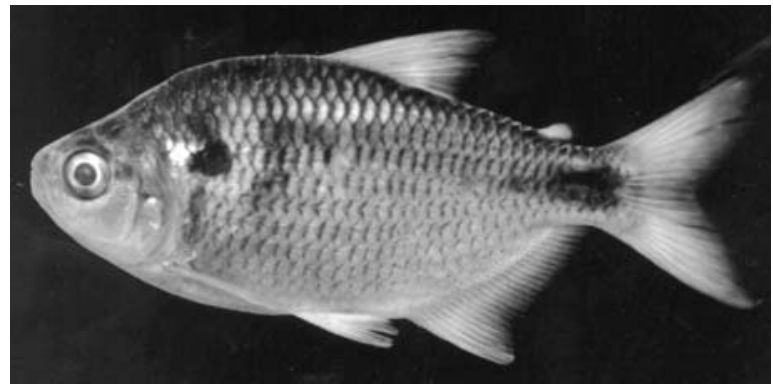

Figure 1 - Astyanax altiparanae (lambari-de-rabo-amarelo). Standard lenght $=8 \mathrm{~cm}$.

From April to November (autumn through spring) 2003, 33 adult $A$. altiparanae were caught from a site ( $24^{\circ} 26^{\prime} 22^{\prime}$ ' S, 5306'36” W) on the Ribeirão Ficha (RF) in Ubiratã municipality. The Ribeirão Ficha is a narrow creek about $2 \mathrm{~m}$ wide that flows into the Piquiri River, a tributary of the Paraná River. Both sides of the creek are covered by a riparian vegetation of about $20 \mathrm{~m}$ wide which shades its surface. Water mean temperature oscillates between $15^{\circ} \mathrm{C}$ in winter and $27^{\circ} \mathrm{C}$ in summer (Estado do Paraná, 1987).

Immediately after capture, white skeletal muscle and liver, gill, stomach, gonad, eye, kidney and heart tissue were removed from each specimen and frozen in liquid nitrogen. Tissues were homogenized with plastic sticks in $1.5 \mathrm{~mL}$ microcentrifuge tubes in the presence of Tris/ $\mathrm{HCl}$ $0.02 \mathrm{M}, \mathrm{pH} 7.5$ buffer (1:1 v:w). Carbon tetrachloride $\left(\mathrm{CCl}_{4}\right)$ was added to homogenized liver samples (1:2 v:v) because of the large amounts of fat present in this tissue (Pasteur et al., 1988). Homogenized samples were centrifuged at $45,114 \mathrm{x}$ g for $30 \mathrm{~min}$, at temperatures between $1^{\circ}$ and $5{ }^{\circ} \mathrm{C}$. The supernatant fractions were submitted to horizontal electrophoresis in $15 \%(\mathrm{w} / \mathrm{v})$ corn starch gel (Val et al., 1981)

A total of 13 enzymatic systems were evaluated, which are shown in Table 1 along with their abbreviations. Enzyme nomenclature followed the proposals of Murphy et

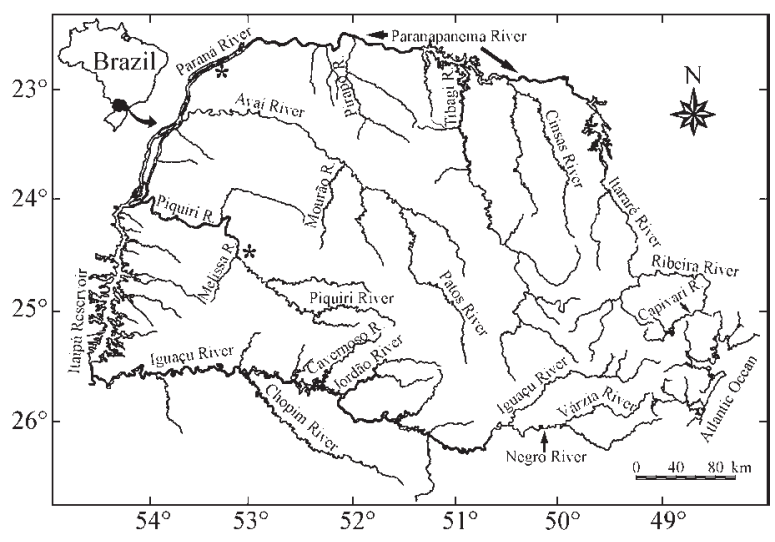

Figure 2 - Sample localities in Upper Paraná River and Ribeirão Ficha, Paraná, Brazil. 
Table 1 - Allele frequencies at 21 loci of Astyanax altiparanae from the Upper Paraná River (PR) and Ribeirão Ficha (RF).

\begin{tabular}{|c|c|c|c|c|c|}
\hline Enzyme* & Tissue & Locus & Allele & $\mathrm{PR}(\mathrm{n}=31)$ & $\mathrm{RF}(\mathrm{n}=33)$ \\
\hline Aspartate aminotransferase (AAT) & Liver & Aat-1 & $a$ & 1.000 & 1.000 \\
\hline \multirow[t]{4}{*}{ Acid phosphatase (ACP) } & Liver, stomach & Acp-1 & $a$ & & 0.160 \\
\hline & & & $b$ & & 0.240 \\
\hline & & & $c$ & 1.000 & 0.440 \\
\hline & & & $d$ & & 0.160 \\
\hline \multirow[t]{5}{*}{ Esterase (EST) } & Liver & Est-1 & $a$ & 0.065 & 0.015 \\
\hline & & & $b$ & 0.903 & 0.970 \\
\hline & & & $c$ & 0.032 & 0.015 \\
\hline & & Est-2 & $a$ & 0.984 & 0.985 \\
\hline & & & $b$ & 0.016 & 0.015 \\
\hline \multirow[t]{3}{*}{ Glucose-3-phosphate dehydrogenase (G-3-PDH) } & Liver & $G 3 p d h-1$ & $a$ & 0.919 & 1.000 \\
\hline & & & $b$ & 0.081 & \\
\hline & & $G 3 p d h-2$ & $a$ & 1.000 & 1.000 \\
\hline \multirow[t]{3}{*}{ glucose-6-phosphate dehydrogenase (G-6-PDH) } & Heart & G6pdh-1 & $a$ & 0.134 & 0.020 \\
\hline & & & $b$ & 0.775 & 0.900 \\
\hline & & & $c$ & 0.091 & 0.080 \\
\hline \multirow[t]{8}{*}{ glucose phosphate isomerase (GPI) } & Heart & $G p i-A$ & $a$ & 0.113 & 0.131 \\
\hline & & & $b$ & 0.339 & 0.109 \\
\hline & & & $c$ & 0.161 & 0.152 \\
\hline & & & $d$ & 0.258 & 0.304 \\
\hline & & & $e$ & 0.097 & 0.130 \\
\hline & & & $f$ & 0.032 & 0.174 \\
\hline & Heart & $G p i-B$ & $a$ & 0.968 & 0.985 \\
\hline & & & $b$ & 0.032 & 0.015 \\
\hline Iditol dehydrogenase (IDDH) & Liver & Iddh-1 & $a$ & 0.581 & 1.000 \\
\hline & & & $b$ & 0.339 & \\
\hline & & & $c$ & 0.080 & \\
\hline \multirow[t]{4}{*}{ Isocitrate dehydrogenase (IDHP) } & Liver & Idhp-1 & $a$ & 0.032 & 0.058 \\
\hline & & & $b$ & 0.968 & 0.923 \\
\hline & & & $c$ & & 0.019 \\
\hline & Heart & $I d h p-2$ & $a$ & 1.000 & 1.000 \\
\hline \multirow[t]{2}{*}{ Lactate dehydrogenase (LDH) } & Gill, heart & $L d h-A$ & $a$ & 1.000 & 1.000 \\
\hline & & $L d h-B$ & $a$ & 1.000 & 1.000 \\
\hline \multirow[t]{5}{*}{ Malate dehydrogenase (MDH) } & Heart & $m M d h-1$ & $a$ & 0.984 & 1.000 \\
\hline & & & $b$ & 0.016 & \\
\hline & & $s M d h-A$ & $a$ & 1.000 & 1.000 \\
\hline & & $s M d h-B$ & $a$ & 1.000 & 0.985 \\
\hline & & & $b$ & & 0.015 \\
\hline \multirow{4}{*}{ Malate dehydrogenase $\mathrm{NADP}^{+}$(MDHP) } & Heart, muscle & Mdhp-1 & $a$ & 0.800 & 1.000 \\
\hline & & & $b$ & 0.200 & \\
\hline & & $M d h p-2$ & $a$ & 0.484 & 1.000 \\
\hline & & & $b$ & 0.516 & \\
\hline Phosphoglucomutase (PGM) & Liver & Pgm-1 & $a$ & 1.000 & 1.000 \\
\hline Superoxide dismutase (SOD) & Liver & Sod-1 & $a$ & 1.000 & 1.000 \\
\hline Frequency of polymorphic loci & & & & 52.38 & 38.10 \\
\hline
\end{tabular}

al. (1996). Electrophoreses conditions were according to the following authors: Boyer et al., (1963) for SOD; Ruvolo-Takasusuki et al., (2002) for ACP and EST; Shaw and Prasad (1970) for AAT, G3PDH, G6PDH, GPI, IDDH, IDHP, LDH, MDH, MDHP and PGM. Standard histochemical staining procedures were used to visualize specific enzymes according to Aebersold et al. (1987). Genetic interpretation of the gels was based on the quaternary structure of the enzymes (Ward et al., 1992).
Data were analyzed using the POPGENE software version 1.31 (Yeh et al., 1999). Genetic variability was estimated using Nei's unbiased heterozygosity $(\mathrm{He})$ or gene diversity (Nei, 1978). The observed $(\mathrm{Ho})$ and expected $(\mathrm{He})$ heterozygosities for each putative loci and the overall loci means were also calculated. Genotypic frequencies were tested for Hardy-Weinberg equilibrium using the chisquared $\left(\chi^{2}\right)$ test. Wright's (1978) F statistics were tested for significance by the $\chi^{2}$ test (Workman and Niswander, 
1970). Differences in $\mathrm{He}$ between the two localities were verified using the t-test (Nei, 1987). Nei's unbiased measure of genetic identity and genetic distance were also calculated (Nei, 1987).

\section{Results}

The electrophoretic patterns obtained in this study are shown in Figure 3 and described below.

Aspartate aminotransferase (AAT) activity was higher in liver than in other tissue but only one electrophoretic band was observed in all analyzed specimens. This phenotype was interpreted as one monomorphic locus.

Acid phosphatase (ACP) activity was restricted to liver tissue and showed the electrophoretic pattern of a dimeric enzyme encoded by a single locus.

Esterase (EST) activity was highly expressed in all tissues, except heart and muscle tissue where its expression was weak. This enzyme was better resolved in liver by using á-naphthyl propionate as substrate. Although three regions of expression were detected only two were interpretable so the bands were considered to be an expression of two polymorphic loci, Est-1 with three alleles and Est-2 with two alleles.

Glucose-3-phosphate dehydrogenase (G-3-PDH) is a dimeric enzyme which showed high expression only in liver tissue, where it showed one polymorphic (G3pdh-1) and one monomorphic (G3pdh-2) locus.

Glucose-6-phosphate dehydrogenase (G-6-PDH) was weakly expressed in heart and muscle tissues but highly expressed in liver tissue with the presence of only one band for each specimen. This phenotype was consid- ered as resulting from only one polymorphic locus with three alleles.

Glucose phosphate isomerase (GPI) is a dimeric enzyme encoded by two polymorphic loci and was highly expressed in liver, heart, muscle, gonad, kidney and stomach tissues where it formed heterodimers. The least anodic bands are encoded by the Gpi-b locus and the most anodic bands by the Gpi-A locus. The $\mathrm{A}_{2}$ isozyme was predominant in eye, gonad, gill, kidney and stomach tissues, while the $\mathrm{B}_{2}$ was prevalent in heart tissue.

Iditol dehydrogenase (IDDH) was expressed only in liver tissue with the presence of only one band for each specimen, suggesting the existence of only one polymorphic locus.

Isocitrate dehydrogenase (IDHP) showed differential expression in the tissues analyzed, one polymorphic locus (Idhp-2) with three alleles being expressed in gill and liver tissue while another monomorphic locus (Idhp-1) was detected in eye, heart and white muscle tissue. Both loci were weakly expressed in gonad, kidney and stomach tissues.

Lactate dehydrogenase (LDH) is a tetrameric enzyme which showed several bands which we interpreted as resulting from the expression of two homozygous loci ( $L d h-A$ and $L d h-B$ ) with variable heterotetramer formation (Figure 3 ). Three bands were observed in heart, presumably representing the $\mathrm{B}_{4}, \mathrm{~A}_{1} \mathrm{~B}_{3}$ and $\mathrm{A}_{3} \mathrm{~B}_{1}$ isozymes. Two loci were expressed in eye, gill and stomach tissues but the $L d h-B$ locus was preferentially expressed in gonad, kidney, and stomach tissues.

Malate dehydrogenase (MDH) is a dimeric enzyme and presented four bands in eye, gill, heart and white muscle tissues. Only two anodic bands were detected In liver

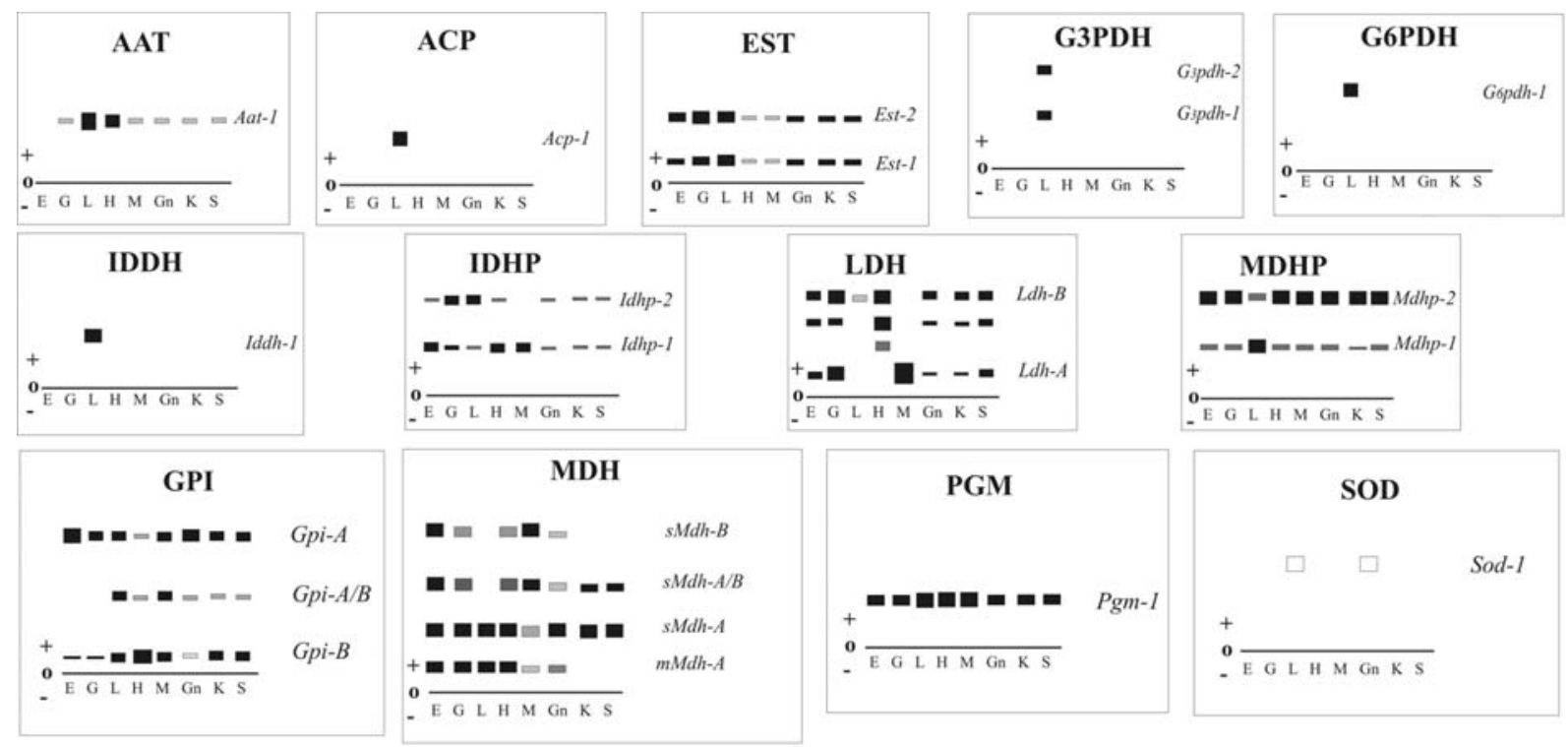

Figure 3 - Electrophoretic pattern and locus designation for 13 enzyme systems of Astyanax altiparanae from the Upper Paraná River and Ribeirão Ficha, Paraná, Brazil. Type of tissue: $\mathrm{E}=$ eye; $\mathrm{G}=$ gill; $\mathrm{L}=$ liver; $\mathrm{H}=$ heart; $\mathrm{M}=$ white muscle; $\mathrm{Gn}=$ gonad; $\mathrm{K}=\mathrm{kidney} ; \mathrm{S}=$ stomach. 
tissue, while both kidney and stomach tissue exhibited two intermediary bands. This pattern was interpreted as the expression of three loci $\left({ }_{m} M D H-1,{ }_{S} M D H-A\right.$ and $\left.{ }_{S} M D H-B\right)$ with heterodimer formation between the ${ }_{S} M D H-A$ and ${ }_{S} M D H-B$ loci.

Malate dehydrogenase $\mathrm{NADP}^{+}(\mathrm{MDHP})$ showed the typical electrophoretic pattern of enzymes encoded by two loci (Mdhp-1 and Mdhp-2). The Mdhp-2 locus was strongly expressed in all tissues except liver, which showed a stronger expression of Mdhp-1locus.

Phosphoglucomutase (PGM) exhibited only one band, which is typical of monomeric enzyme encoded by one monomorphic locus.

Superoxide dismutase (SOD), expression of this enzyme was restricted to liver and gonad tissues, showing a pattern of only one band encoded by a monomorphic locus.

We identified 21 putative enzyme loci in $31 \mathrm{~A}$. altiparanae specimens, $11(52.38 \%)$ of the loci being polymorphic in PR fish and 8 (38.10\%) in RF fish polymorphic (Table 1). For the PR population $H o=0.0753 \pm 0.0404$ and $H e=0.1518 \pm 0.0493$ while for the RF population $H o=0.0730 \pm 0.0399$ and $H e=0.0905 \pm 0.0464$ (Table 2). The $t$-test revealed that the difference between estimated $\mathrm{He}$ values for the two populations was not significant $(t=0.9055,19$ degrees of freedom (df)). Nei's unbiased measure of genetic identity was 0.9549 and the genetic distance between populations was 0.0462 .

The data revealed that the G6pdh-1, Iddh-1, Mdhp-1 and $M d h p-2$ loci in the PR population and the Acp-1 locus in the RF population were not in Hardy-Weinberg equilibrium. All 31 specimens in the PR population were homozygotes for the putative $A c p-1(c)$ and $s M d h-B(a)$ alleles and the 33 specimens in the RF population were homozygotes for the G6pdh-1(a), Iddh-1(a), mMdh-1(a), Mdhp-1(a) and Mdhp-2(a) alleles. The Wright's (1978) F statistics showed that there was a significant excess of homozygotes and the $\mathrm{F}_{\text {st }}$ values showed that the two populations differ significantly at the Acp-1, G3pdh-1, Gpi-A,Iddh-1, Mdhp-1, and Mdhp-2 loci (Table 3).

\section{Discussion}

Our allozyme starch gel electrophoretic study detected high allozyme variability between the $A$. altiparanae populations from the Upper Paraná River (PR) and the Ribeirão Ficha (RF). Other workers have also used molecular markers to compare the genetic variability of $A$. altiparanae populations from other Brazilian rivers. Moysés and Almeida-Toledo (2002) studied the genetic variability of the mitochondrial DNA (mtDNA) of Astyanax lacustris from the São Francisco River basin and A. altiparanae from the PR basin using the restriction fragment length polymorphism (RFLP) method and found differences between these two populations. Prioli et al. (2002) used random amplified polymorphic DNA (RAPD) and mtDNA markers to demonstrate strong genetic similarities
Table 2 - Obtained $(\mathrm{Ho})$ and expected $(\mathrm{He})$ heterozygosity per locus of Astyanax altiparanae from the Upper Paraná River (PR) and Ribeirão Ficha (RF).

\begin{tabular}{|c|c|c|c|c|c|c|}
\hline \multirow[b]{2}{*}{ Locus } & \multicolumn{3}{|c|}{ PR } & \multicolumn{3}{|c|}{$\mathrm{RF}$} \\
\hline & $\mathrm{N}$ & Ho & $\mathrm{He}$ & $\mathrm{n}$ & Ho & $\mathrm{He}$ \\
\hline Aat-1 & 31 & 0.0000 & 0.0000 & 31 & 0.0000 & 0.0000 \\
\hline Acp-1 & 31 & 0.0000 & 0.0000 & 25 & 0.5600 & 0.6976 \\
\hline Est-1 & 31 & 0.1290 & 0.1790 & 33 & 0.0606 & 0.0592 \\
\hline Est-2 & 31 & 0.0323 & 0.0317 & 32 & 0.0303 & 0.0298 \\
\hline$G_{3} p d h-1$ & 31 & 0.1613 & 0.1483 & 33 & 0.0000 & 0.0000 \\
\hline$G_{3} p d h-2$ & 31 & 0.0000 & 0.0000 & 33 & 0.0000 & 0.0000 \\
\hline$G_{6} p d h-1$ & 22 & 0.0000 & 0.3760 & 25 & 0.0400 & 0.1832 \\
\hline$G p i-A$ & 31 & 0.8387 & 0.7492 & 24 & 0.6667 & 0.7266 \\
\hline$G p i-B$ & 31 & 0.1613 & 0.1483 & 33 & 0.0303 & 0.0298 \\
\hline$I d d h-1$ & 31 & 0.1613 & 0.5489 & 23 & 0.0000 & 0.0000 \\
\hline Idhp-1 & 31 & 0.0000 & 0.0000 & 26 & 0.0000 & 0.0000 \\
\hline Idhp-2 & 31 & 0.0645 & 0.0624 & 32 & 0.1154 & 0.1442 \\
\hline$L d h-A$ & 31 & 0.0000 & 0.0000 & 33 & 0.0000 & 0.0000 \\
\hline$L d h-B$ & 31 & 0.0000 & 0.0000 & 33 & 0.0000 & 0.0000 \\
\hline$m M d h-1$ & 31 & 0.0323 & 0.0317 & 33 & 0.0000 & 0.0000 \\
\hline$s M d h-A$ & 31 & 0.0000 & 0.0000 & 33 & 0.0000 & 0.0000 \\
\hline$s M d h-B$ & 31 & 0.0000 & 0.0000 & 33 & 0.0303 & 0.0298 \\
\hline Mdhp-1 & 31 & 0.0000 & 0.4121 & 32 & 0.0000 & 0.0000 \\
\hline$M d h p-2$ & 31 & 0.0000 & 0.4995 & 33 & 0.0000 & 0.0000 \\
\hline Pgm-1 & 31 & 0.0000 & 0.0000 & 33 & 0.0000 & 0.0000 \\
\hline Sod-1 & 31 & 0.0000 & 0.0000 & 33 & 0.0000 & 0.0000 \\
\hline Mean & & 0.0753 & 0.1518 & & 0.0730 & 0.0905 \\
\hline Standard e & & 0.0404 & 0.0493 & & 0.0399 & 0.0464 \\
\hline
\end{tabular}

between $A$. altiparanae populations from the Keller and Pirapó rivers in the PR basin and the Iguaçu River. Leuzzi et al. (2004) used RAPD to analyze the genetic variability of $A$. altiparanae from four localities in the Capivara dam, one from the Rosana dam (downstream of the Capivara dam) and one from the Jurumirim dam (upstream of the Capivara dam) of the Paranapanema River (a Brazilian tributary of the Paraná River) and reported high genetic variability and high population differentiation.

The $A$. altiparanae phenotypes we obtained for the 13 enzymatic systems studied were similar to those previously demonstrated for other Characiformes from the PR basin (Revaldaves et al., 1997; Renesto et al., 1997, 2001; Chiari and Sodré, 1999; Peres et al., 2002) and for Siluriformes (Almeida and Sodré, 1998; Zawadzki et al., 1999, 2000a, 2000b; Renesto et al., 2000). Our data revealed that $A$. altiparanae carries high genetic variability, $52.38 \%$ of polymorphic loci in PR and $38.10 \%$ in the RF. The expected genetic heterozygosity was estimated as 0.1518 for the PR population and 0.0933 for the RF population, which is higher than the average of 0.051 for 195 piscine species from several world-wide localities reported in the review 
Table 3 - Wright's statistics for Astyanax altiparanae from the Upper Paraná River (PR) and Ribeirão Ficha (RF).

\begin{tabular}{|c|c|c|c|c|c|c|c|}
\hline \multirow[b]{2}{*}{ Locus } & \multicolumn{2}{|c|}{ PR } & \multicolumn{2}{|c|}{$\mathrm{RF}$} & \multicolumn{3}{|c|}{ Overall } \\
\hline & $\mathrm{n}$ & $\mathrm{F}_{\text {is }}$ & $\mathrm{n}$ & $\mathrm{F}_{\text {is }}$ & $\mathrm{F}_{\text {is }}$ & $\mathrm{F}_{\text {it }}$ & $\mathrm{F}_{\mathrm{st}}$ \\
\hline Aat-1 & 31 & & & & 0.0000 & 0.0000 & 0.0000 \\
\hline Acp-1 & 31 & & 25 & 0.1972 & $0.1972 *$ & $0.3838 *$ & $0.2324 *$ \\
\hline Est-1 & 31 & 0.2791 & 33 & -0.0233 & 0.2039 & 0.2157 & 0.0148 \\
\hline Est-2 & 31 & -0.0164 & 32 & -0.0154 & -0.0159 & -0.0159 & 0.0000 \\
\hline G3pdh-1 & 31 & -0.0877 & 33 & & -0.0877 & $-0.0420 *$ & $0.0420 *$ \\
\hline G3pdh-2 & 31 & & 33 & & 0.0000 & 0.0000 & 0.0000 \\
\hline G6pdh-1 & 22 & $1.0000^{*}$ & 25 & $0.7817^{*}$ & $0.9285^{*}$ & 0.9303 & 0.0260 \\
\hline Gpi-A & 31 & -0.1194 & 24 & 0.0824 & $0.1062 *$ & $0.1221 *$ & $0.0705^{*}$ \\
\hline$G p i-B$ & 31 & -0.0877 & 33 & -0.0154 & -0.0756 & $-0.0503 *$ & 0.0235 \\
\hline Iddh-1 & 31 & $0.7062 *$ & 23 & & $0.7062 *$ & $0.7728 *$ & $0.2268 *$ \\
\hline Idhp-1 & 31 & -0.0333 & 26 & 0.2000 & $0.1295^{*}$ & $0.1358 *$ & 0.0072 \\
\hline Idhp-2 & 31 & & 32 & & 0.0000 & 0.0000 & 0.0000 \\
\hline$L d h-A$ & 31 & & 33 & & 0.0000 & 0.0000 & 0.0000 \\
\hline$L d h-B$ & 31 & & 33 & & 0.0000 & 0.0000 & 0.0000 \\
\hline$m M d h-1$ & 31 & -0.0164 & 33 & & $-0.0164 *$ & -0.0081 & 0.0081 \\
\hline$s M d h-A$ & 31 & & 33 & & 0.0000 & 0.0000 & 0.0000 \\
\hline$s M d h-B$ & 31 & & 33 & -0.0154 & -0.0154 & -0.0076 & 0.0076 \\
\hline$M d h p-1$ & 31 & $1.0000 *$ & 32 & & $1.0000 *$ & $1.0000 *$ & $0.1698 *$ \\
\hline$M d h p-2$ & 31 & $1.0000 *$ & 33 & & $1.0000 *$ & $1.0000^{*}$ & $0.3478 *$ \\
\hline Pgm-1 & 31 & & 33 & & 0.0000 & 0.0000 & 0.0000 \\
\hline Sod-1 & 31 & & 33 & & 0.0000 & 0.0000 & 0.0000 \\
\hline Mean & & 0.5039 & & 0.1934 & 0.3919 & 0.4804 & 0.1455 \\
\hline
\end{tabular}

$*$ Statistically significant at $\mathrm{p}=0.05$.

by Ward et al. (1992) but similar to other Brazilian Characiformes. Revaldaves et al. (1997) estimated that the expected heterozygosity of Prochilodus lineatus from the PR was 0.13, while Chiari and Sodré (1999) analyzed populations of five anostomid species from the Tibagi River (a tributary of the Paranapanema River) and found expected heterozygosity values of 0.142 for Leporinus elongatus, 0.132 for Leporinus frederici, 0.09 for Leporinus obtusidens, 0.092 for Schizodon nasutus and 0.072 for Schizodon intermedius. The expected heterozygosity of Hoplias malabaricus was estimated as 0.14 for both a Paraná River and a lagoon population (Peres et al., 2002). However, lower heterozygosity values have been reported for Iguaçu River (Brazil) fish species, Renesto et al., (1997) having reported that three undescribed Astyanax species endemic to the Iguaçu River showed low estimated expected heterozygosity $(0.097,0.082$ and 0.061 for Astyanax sp. B, C and F). Low estimated expected heterozygosity has also been reported for two other Iguaçu River fish, 0. 063 for Crenicichla iguassuensis (Renesto et al., 2001) and 0.024 for Pimelodus ortmanni (Renesto et al., 2000). These low expected heterozygosity values for Iguaçu River species may be due to regulation of invariable structural genes which guarantee phenotypic plasticity (Chippari-Gomes et al., 2003).

In our study, although the expected heterozygosities estimated for the two populations analyzed were not significantly different $(\mathrm{t}=0.9054)$, significant $\mathrm{F}_{\text {st }}$ values were found for Acp-1, G ${ }_{3}$ pdh-1, Gpi-A, Iddh-1, Mdhp-1 and Mdhp-2 (Table 3). Furthermore, a few alleles present in one population were missing in the other. If the $A c p-1(c)$ and $s M d h-B(a)$ allele frequencies in the PR population were equal to those of the RF population the probability that all the 31 PR specimens were homozygotes would be $7.835 \mathrm{x}$ $10^{-23}\left(0.44^{2 \times 31}\right)$ for $A c p-1(c)$ and $0.3918\left(0.985^{2 \times 31}\right)$ for $s M d h-B(a)$. On the other hand, if the $G_{3} p d h-1(a), \operatorname{Iddh}-1(a)$, mMdh-1(a), Mdhp-1(a) and Mdhp-2(a) allele frequencies of the RF population were about the same as for the PR population the probability that all the $33 \mathrm{RF}$ specimens were homozygotes for $G_{3} p d h-1(a)$, Iddh-1(a), mMdh-1(a), Mdhp-l(a) and Mdhp-2(a) would be 0.0038, 2.7266 x 10 $10^{-16}$, $0.3449,4 \times 10^{-7}, 1.5841 \times 10^{-21}$ respectively. Considering the number of fish analyzed, the probability that the $G_{3} p d h-1(a), \quad I d d h-1(a), \quad m M d h-1(a), \quad M d h p-1(a)$ and Mdhp-2(a) alleles were not detected in the PR population is extremely low. This may be due to lack of gene flow between the two populations because they are separated by 
about $440 \mathrm{~km}$ of river which may have allowed the accumulation of different mutations. Our data indicated that the PR and RF populations are genetically differentiated.

The expected heterozygosity for each locus ranged from zero to 0.7492 in the A. altiparane population from the PR floodplain and from zero to 0.7266 for the RF population, with the $G p i-A$ locus being the most polymorphic (Table 2). Johnson (1974) suggested that glucose phosphate isomerase (GPI) polymorphism could be considered as a metabolic alternative, since this enzyme can have a regulatory function and that GPI polymorphism enhances fitness by providing metabolic compensation in fluctuating environments.

We found a significant excess of homozygotes for the G6pdh-1, Iddh-1, Mdhp-1 and Mdhp-2 loci in the PR population and at the G6pdh-1 locus in the RF population (Table 3). Such high homozygosity should not be attributable to either inbreeding or genetic drift because A. altiparanae is highly abundant in the rivers studied, so it may be that selection for homozygotes is occurring at these loci.

The high genetic variability of $A$. altiparanae detected by us may be explained by natural selection for heterozygote advantage at polymorphic loci. Because of the large populations the high genetic variability of $A$. altiparanae may also be due to the accumulation of neutral or quasi-neutral mutations (Kimura and Ohta, 1971). Cytogenetic studies have suggested that $A$. altiparanae is a complex of cryptic species, several authors having reported the same diploid number $(2 \mathrm{n}=50)$ but different karyotype formulae and a different number of NOR-bearing chromosomes in this fish (Vale and Martins-Santos, 1998; Daniel-Silva and Almeida-Toledo, 2001; Pacheco et al., 2001; Porto and Martins-Santos, 2002; Fernandes and Martins-Santos, 2005).

Because of its important ecological role, the genetic variability of $A$. altiparanae should be taken into account in conservation policies to assure the evolutionary future of this species.

\section{Acknowledgments}

The authors are grateful to Horácio F. Júlio Jr. and Gilmar Lassala for help with specimen sampling and identification, Isabel C.M. dos Santos for help with the figures, Maria de Fátima P.S. Machado for help with gel interpretation and Laudenir M. Prioli for helpful discussions. We also thank the Núcleo de Pesquisa em Limnologia, Ictiologia e Aqüicultura da Universidade Estadual de Maringá for logistic support, Corns Products Brazil LTDA for providing corn starch freely and CAPES and PELD/CNPq for financial support.

\section{References}

Abes SS (1998) Padrões espaço-temporais na composição específica e estrutura trófica da taxocenose de peixes do riacho
Água Nanci, bacia do Alto Rio Paraná. Dissertação de Mestrado, Universidade Estadual de Maringá, Maringá.

Aebersold PB, Winans GA, Tell DJ, Milner GB and Utter M (1987) Manual for starch gel electrophoresis: A method for the detection of genetic variation. NOAA Technical Report NMFS 61:1-17.

Agostinho AA, Gomes LC and Zalewski M (2001) The importance of floodplains for the dynamics of fish communities of the upper river Paraná. Ecohydrology \& Hydrobiology 1-2:209-217.

Almeida FS de and Sodré LMK (1998) Analysis of genetic variability in three species of Pimelodidae (Ostariophysi, Siluriformes). Genet Mol Biol 21:487-492.

Boyer SH, Fainer DC and Naughton MA (1963) Myoglobin: Inherited structural variation in man. Science 140:1228-1231.

Chiari L and Sodré LMK (1999) Genetic variability in five species of anostomidae (Ostariophysi, Characiformes). Genet Mol Biol 4:517-523.

Chippari-Gomes AR, Leitão MAB, Paula-Silva MN, MesquitaSaad LSB and Almeida-Val VMF (2003) Metabolic adjustments in Satanoperca aff. Jurupari (Perciformes, Cichlidae) Genet Mol Biol 26:27-32.

Daniel-Silva MFZ and Almeida-Toledo LF (2001) Chromosome R-banding pattern and conservation of a marker chromosome in four species, genus Astyanax (Characidae, Tetragonopterinae). Caryologia 54:209-215.

Estado do Paraná - Secretaria de Estado de Agricultura e do Abastecimento. Instituto de Terras, Cartografia e Florestas (1987) Atlas do Estado do Paraná.

Fernandes CA and Martins-Santos IC (2005) Cytogenetic studies in two populations of Astyanax altiparanae (Pisces, Characiformes). Hereditas 141 (in press)

Garutti V and Britski HA (2000) Descrição de uma espécie nova de Astyanax (Teleostei, Characidae) da bacia do Alto Rio Paraná e considerações gerais sobre as demais espécies do gênero da bacia. Comum Mus Ciênc Tecnol PUCRS Sér Zool 13:65-88

Johnson GB (1974) Enzyme polymorphism and metabolism. Science 184:28-37.

Julio Jr HF and Agostinho AA (2003) Introduced species into the Upper Paraná River floodplain by elimination of a geographical barrier and stocking programs. Joint Meeting of Ichthyologists and Herpetologists, Manaus, 26/6 a 1/7/2003.

Kimura M and Ohta T (19171) Protein polymorphism as a phase of molecular evolution. Nature 229:467-469.

Leuzzi MSP, Almeida FS, Orsi ML and Sodré MLK (2004) Analysis by RAPD of the genetic structure of Astyanax altiparanae (Pisces, Characiformes) in reservoirs of the River Paranapanema. Brazil Genet Mol Biol 27:355-362.

Luz KDG and Okada EK (1999) Diet and dietary overlap of three sympatric fish species in lakes of the Upper Paraná River Floodplain. Braz Arch Biol Technol 42:441-447.

Moysés CB and Almeida-Toledo LF (2002) Restriction fragment length polymorphisms of mitochondrial DNA among five freshwater fish species of the genus Astyanax (Pisces, Characidae) Genet Mol Biol 25:401-407.

Murphy RW, Sites Jr JW, Buth DG and Haufler CH (1996) Poteins: Isozyme electophoresis. In: Hillis DM, Moritz C and Mable BK (eds) Molecular Systematics. Sunderland, Sinnauer Assoc., pp 51-120. 
Nei M (1978) Estimation of average heterozygosity and genetic distance from a small number of individuals. Genetics 89:583-590.

Nei M (1987) Molecular Evolutionary Genetics. N. York, Columbia University Press, 512 pp.

Oliveira AV, Prioli AJ, Prioli SMAP, Pavanelli, CS, Julio Jr HF and Panarari RS (2002) Diversity and genetic distance in populations of Steindachnerina in the upper Paraná River floodplain. Genetica 115:259-267.

Oliveira AV (2004) Relações genéticas entre populações do gênero Cichla introduzidas na bacia do Rio Paraná, evidenciadas por marcadores nucleares e do genoma mitocondrial. PhD. Thesis, Universidade Estadual de Maringá, Maringá.

Pacheco RB, Giuliano-Caetano L and Dias AL (2001) Cytotypes and multiple NORs in an Astyanax altiparanae population (Pisces, Tetragonopterinae). Chromosome Sci 5:109-114.

Pasteur N, Pasteur G, Bonhomme F, Catalan J and BrittonDavidian J (1988) Practical Isozyme Genetics. Ellis Horwood Limited, Chichester, 215 pp.

Peres MD, Renesto E, Lapenta AS and Zawadzki CH (2002) Genetic variability in Hoplias malabaricus (Osteichthyes, Erytrinidae) in fluvial and lacustrine environments in the Upper Paraná River floodplain (Paraná State, Brazil). Biochem Genet 40:209-223.

Porto FE and Martins-Santos IC (2002) Diversidade cariotípica em populações de Astyanax altiparanae (Pisces, Characidae) das bacias do Rio Paraná e Iguaçu. IX Simpósio de Citogenética e Genética de Peixes pp 3.

Prioli SMAP, Prioli AJ, Júlio-Jr HF, Pavanelli CS, Oliveira AV, Carrer H, Carraro DM and Prioli LM (2002b) Identification of Astyanax altiparanae (Teleostei, Characidae) in the Iguaçu River, Brazil, based on mitochondrial DNA and RAPD markers. Genet Mol Biol 25:421-430.

Renesto E, Zawadzki CH and Revaldaves E (2000) Genetic evidence for two species of the genus Pimelodus Lacépède, 1803 (Siluriformes, Pimelodidae) in the Iguaçu River (Brazil). Genet Mol Biol 23:809-813.

Renesto E, Zawadzki CH and Revaldaves E (2001) Biochemical Taxonomy of Crenicichla (Pisces, Perciformes, Cichlidae) of the Iguaçu River. Brazilian Archives of Biol Technol 44:15-22.

Renesto E and Zawadzki CH (1997) Taxonomia bioquímica de Astyanax do reservatório de Segredo. In: Agostinho AA and Gomes LC (eds) Reservatório de Segredo: Bases Ecológicas para Manejo. Ed. Universidade Estadual de Maringá, Maringá, pp 85-96.

Revaldaves E, Renesto E and Machado MFPS (1997) Genetic variability of Prochilodus lineatus (Characiformes, Prochilodontidae) in the Upper Paraná river. Braz J Genet 20:381-388.

Ruvolo-Takasusuki MCC, Machado MFPS and Conte H (2002) Esterase-3 polymorphism in the sugarcane borer Diatraea saccharalis. Genet Mol Biol 25:61-64.

Sekine ES, Prioli AJ, Prioli SMAP and Júlio Jr HF (2002) Genetic differentiation among populations of Pseudoplatystoma corruscans (Agassiz, 1829) (Osteichthyes, Pimelodidae) isolated by the Guaira Falls in the Paraná River. Acta Scient 24:507-512.
Shaw CR and Prasad R (1970) Starch gel electrophoresis of enzymes: A compilation of recipes. Biochem Genet 4:297-320

Thomaz SM, Roberto MC and Bini LM (1997) Caracterização limnológica dos ambientes aquáticos e influência dos níveis fluviométricos. In: Vazzoler AEA, Agostinho A and Hahn NS (eds) A Planície de Inundação do Alto Rio Paraná: Aspectos Físicos, Biológicos e Socioeconômicos. Ed. Universidade Estadual de Maringá, Maringá, pp 250-265.

Val AL, Schwantes AR, Schwantes MLB and De Luca PH (1981) Amido hidrolisado de milho como suporte eletroforético. Ci Cult 33:737:741.

Vale JD and Martins-Santos IC (1998) Estudo citogenético de duas populações de Astyanax bimaculatus (Pisces, Characidae). VII Simpósio de Citogenética Evolutiva Aplicada de Peixes Neotropicais, pp A8

Vazzoler AEA, Suzuki HI, Marques EE and Lizama MLAP (1997) Primeira maturação gonadal, períodos e áreas de reprodução. In: Vazzoler AEA, Agostinho A and Hahn NS (eds) A Planície de Inundação do Alto Rio Paraná: Aspectos Físicos, Biológicos e Socioeconômicos. Ed. Universidade Estadual de Maringá, Maringá, pp 250-265.

Vida G (1994) Global issues of genetic diversity. In: Loeschcke V, Tomiuk J and Jain SK (eds) Conservation Genetics. Basel, Birkhauser Verlag, pp 9-19.

Yeh FC, Yang R and Boyle T (1999) POPGENE Version3.1: Microsoft Window based freeware for population genetics analysis. University of Albert and Center for International Forestry Research.

Ward RD, Skibinski DOF and Woodward M (1992) Protein heterozygosity, protein structure and taxonomic differentiation. Evol Biol 26:73-59.

Ward RD, Woodward M and Skibinski DOF (1994) A comparison of genetic diversity levels in marine, freshwater, and anadromous fishes. J Fish Biol 44:213-232.

Workman PL and Niswander JD (1970) Population studies on southwestern Indian tribes. II. Local genetic differentiation in the Papago. Amer J Hum Gen 22:24-29.

Wright S (1978) Evolution and the Genetics of Population, v 4. Variability Within and Among Natural Population. University of Chicago Press, Chicago, pp 79-103.

Zawadzki CH, Renesto E and Bini LM (1999) Genetic and morphometric analysis of three species of the genus Hypostomus Lacépède 1803 (Osteichthyes, Loricariidade) from Iguaçu River basin (Brazil). Rev Suisse de Zool 106:91-105.

Zawadzki CH, Machado MFPS and Renesto E (2000a) Differential expression for tissue-specific isozymes in three species of Hypostomus Lacépède 1803 (Teleostei, Loricariidade). Bioch Syst Ecol 29:911-922.

Zawadzki CH, Reis RE and Renesto E (2000b) Allozyme discrimination of three species of Loricariichthys (Siluriformes, Loricariidae) from southern Brazil. Rev Suisse de Zool 107:663-674.

Zawadzki CH, Renesto E, Reis RE, Moura MO and Mateus RP (2005) Allozyme relationships in hypostomines (Teleostei, Loricariidae) from the Itaipu Reservoir, Upper Rio Paraná basin, Brazil. Genetica 123:271-283.

Associate Editor: Horacio Schneider 